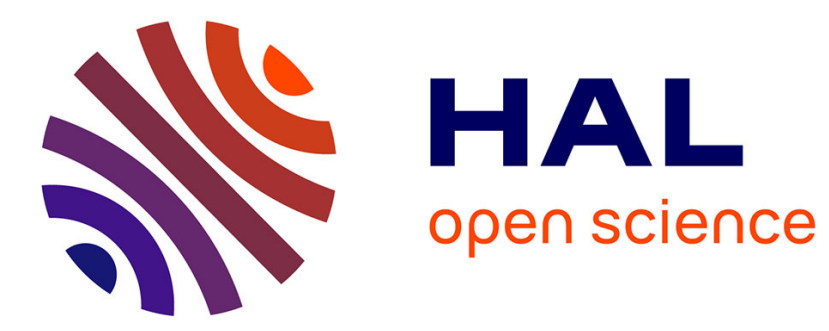

\title{
TCO Evaluation in Physical Asset Management: Benefits and Limitations for Industrial Adoption Irene Roda, Marco Garetti
}

\section{To cite this version:}

Irene Roda, Marco Garetti. TCO Evaluation in Physical Asset Management: Benefits and Limitations for Industrial Adoption. IFIP International Conference on Advances in Production Management Systems (APMS), Sep 2014, Ajaccio, France. pp.216-223, 10.1007/978-3-662-44733-8_27 . hal01387183

\section{HAL Id: hal-01387183 \\ https://hal.inria.fr/hal-01387183}

Submitted on 25 Oct 2016

HAL is a multi-disciplinary open access archive for the deposit and dissemination of scientific research documents, whether they are published or not. The documents may come from teaching and research institutions in France or abroad, or from public or private research centers.
L'archive ouverte pluridisciplinaire HAL, est destinée au dépôt et à la diffusion de documents scientifiques de niveau recherche, publiés ou non, émanant des établissements d'enseignement et de recherche français ou étrangers, des laboratoires publics ou privés. 


\title{
TCO evaluation in physical asset management: benefits and limitations for industrial adoption
}

\author{
Irene Roda ${ }^{1}$, Marco Garetti $^{1}$ \\ ${ }^{1}$ Politecnico di Milano, Department of Management, Economics and Industrial Engineering \\ Milan, Italy $\{$ i r ene. r oda, $\operatorname{mar}$ co. gar et $t$ i $\} @$ @ol i mi . i t
}

\begin{abstract}
Nowadays, the evaluation of the total cost of ownership (TCO) of an asset for supporting informed decision-making both for investments and managerial issues within the asset management framework is gaining increasing attention in industry. Nevertheless its application in practice is still limited. The aim of this paper is to analyze the benefits and limitations of the adoption of TCO evaluation in asset management. Based on a literature review, the paper defines a framework that categorizes the benefits and potential applications that a TCO model can have for different stakeholders. Together with that, industry related issues that influence its implementation are also considered. Finally, empirical evidences are analyzed through a multiple case study to understand if those benefits are recognized in practice and which are the limitations for the practical adoption of a TCO model that should allow exploiting such benefits.
\end{abstract}

Keywords. Total Cost of Ownership, asset management

\section{Introduction}

In the industrial sector, the operating time of the production asset after the green-field investment is typically long and during such time numerous rebuilds, replacements and expansion investments take place. All of these decisions, together with the chosen operations and maintenance strategies, affect the productivity of the physical capital (Komonen et al., 2006; Tam and Price, 2008). In order to meet the challenge of low returns on investment and realize value from asset, enterprises need to adopt an asset management strategy and system (ISO 55000:2014(E), 2014). Within it, one of the challenges for supporting decision-making along the asset lifecycle, is to improve the quantification process of costs so to be able to evaluate the total cost of a production system throughout its life cycle (i.e. the Total Cost of Ownership (TCO)) (IAM, 2012; Parra et al., 2009). 


\section{Methodology}

This paper aims at defining a framework that categorizes the benefits and potential applications that a TCO model can have in asset management for different stakeholders. In order to do so, an extensive literature review has been developed as a keyword search, both through library services (Scopus, Google Scholar etc.) and a wider surfing in the web to consider journals and conferences publications, but also white papers and industrial reports. The analytic categories that allowed the classification of the reviewed literature and the definition of the framework have been derived both deductively considering the body of theory in the physical asset management and inductively from the material analyzed by means of generalization (Mayring, 2003). Once defined the framework, empirical evidences have been analyzed so to confirm it from a practical point of view. This also allowed identifying the main limitations for the adoption of TCO models, trough the development of a multiple case study. Details on the related methodology are given in Section 4.

\section{TCO applications and benefits: definition of a framework}

It is widely accepted in the academic literature (Schuman and Brent, 2005) that TCO should be an integral part of an asset management strategy and the same is assessed by the body of standards ISO 55000 on asset management (ISO 55000:2014(E), 2014). In the latter, it is indicated that: "[...] Life cycle cost, which may include capital expenditure, financing and operational costs, should be considered in the decisionmaking process". Moreover, companies are acknowledging how TCO can represent a reliable economic-sound support for taking decisions and to convey the information to people in different parts / functions of the same organization, or outside the company, such us costumers / suppliers. The ability to effectively identify cost drivers and manage cost reductions is a competitive advantage for companies (Heilala et al., 2006).

\subsection{The framework}

Based on the literature review, a framework has been developed identifying the benefits for a company of having a TCO evaluation model supporting the decision-making process. The framework is organized on three main dimensions: i) type of stakeholder, ii) type of supported decision, iii) phase of the life cycle.

- Type of stakeholder. Different stakeholders with different perspectives can be interested in TCO analysis. Given the meaning itself of TCO, it is evident that asset users (industrial equipment or plant owners / managers) are the primary interested subjects. Nevertheless TCO is also a relevant issue for asset providers (industrial equipment or plant builders / manufacturers) (Barringer, 2003). Clearly it has to be considered that each of the two types of stakeholders has some common and some distinguishing reasons for interest on TCO. Besides, it must be considered that the 
ability of a provider to perform TCO evaluation is affected by the quality of information available in a higher way than the users' one (Korpi and Ala-Risku, 2008).

- Type of supported decision. A TCO model has potentiality to support different kinds of decisions. In particular, two main categories have been identified: (i) configuration decisions and (ii) management decisions. The first category includes all those decisions that have direct influence on the asset configuration, while the second one refers to those decisions that deal with the management, operation and maintenance of the asset.

- Phase of life cycle. TCO analysis is preferably carried out in any and all phases of an asset's life cycle to provide input to decision makers (Kawauchi and Rausand, 1999; Schuman and Brent, 2005). According to the conventional perspective, the lifecycle of an asset is composed by three main phases: beginning of life (BoL) including the activities for bringing an asset into operation (conceptualization, design, construction, installation and acquisition), middle of life (MoL) including the activities involved in asset operation and maintenance and finally the end of life (EoL) involving the final retirement of the asset (Amadi-Echendu, 2004).

The developed framework (Table 1) shows which benefits a TCO model can bring to each of the two types of stakeholder at each lifecycle phase by supporting different kinds of decisions (configuration or management decisions). In the following subsections the content of the framework is articulated considering each lifecycle phase.

BoL- According to several authors; cost must be an active rather than a resultant factor throughout the system design process (Fabrycky and Blanchard, 1991; Waghmode and Sahasrabudhe, 2012; Woodward, 1997). Though, generally speaking only $15 \%$ of the total TCO is consumed during the design phase, research has shown that as much as $85 \%$ of the remaining TCO is determined by decisions made during this stage (Lad and Kulkarni, 2008). TCO evaluation at this step allows providers and users to economically evaluate different scenarios at a pre-design step (Carpentieri and Papariello, 2006); determining the most cost efficient design amongst a set of alternatives; identifying cost drivers for design changes and optimization and, determining the cost of a design for budgetary purposes (Korpi and Ala-Risku, 2008). TCO can be seen also as a procurement (from the user perspective) and sales and marketing (from the provider perspective) tool. (Snelgrove, 2012) asserts that at the heart of pricing and selling in the twenty-first century is the ability to price based on created value. Moreover, TCO allows abandoning traditional feature-based marketing showing how the offered asset creates specific benefits considering its lifecycle and its effect on customer profitability. On the other side, through TCO, users are able to support their suppliers selection and evaluation steps (Ellram and Siferd, 1998). In the BoL phase the supplier can also be interested in TCO evaluation in case there is the possibility to enter into a service contract. TCO model is also able to support investment decisions supporting budget planning and costs control helping preventing decision makers from incurring investments which might be cheaper in acquisition, but significantly more expensive in O\&M and consequently in total costs over their life cycle. Finally TCO plays a supporting role during the construction \& installation phase for asset providers. In fact, although it is a late stage in the project for major 
changes, recommendations should still be considered in terms of TCO and the most favorable solution implemented. Spare parts requirement and provision can be evaluated at this phase (Schuman and Brent, 2005).

MoL- The evaluation of TCO and its usage for decision making support does represent a relevant aspect also during the MoL phase of an asset, both for configuration and management decisions, mostly for the asset users. At this stage, the asset is operative and, compared to the design stage, the level of uncertainty for the TCO evaluation is lower (Kawauchi and Rausand, 1999). Opportunities for reduced support costs and more effective support are based on the systematic capture and reuse of all information throughout the equipment life cycle; hence the best scenario is the case where data for technical performance evaluation are regularly collected. If this is not possible, the uncertainty in cost evaluation is anyways lower given that even if the analysis are based on estimations by people working on the field, these are related to an existing and operative asset. The use of TCO in this step can support asset users for configuration decisions such as the evaluation of the reconfiguration of the asset by applying some changes in the current layout for achieving a better availability level, involving also considerations on the WIP level (Tomasella and Parlikad, 2012). Moreover TCO evaluation can support management decisions such as the evaluation of changes in the actual maintenance strategy (Lad and Kulkarni, 2008; Woodward, 1997). Likewise, decisions on the operative conditions of the asset; its utilization and the production strategies can be supported by the TCO evaluation.

EoL- TCO has got relevance also at the End of Life of an asset. In fact, in this stage the asset is taken out of service for disposal or redeployment. In the latter case a potential new TCO may begin (Woodward, 1997), therefore the asset manager may use the TCO evaluation of the existing asset in order to support decisions for rehabilitation or reuse of the asset itself (Asiedu and Gu, 1998; Shahata and Zayed, 2008).

Table 1. Framework

\begin{tabular}{|c|c|c|c|c|}
\hline & \multicolumn{2}{|c|}{ ASSET PROVIDER } & \multicolumn{2}{|c|}{ ASSET USER } \\
\hline & Configuration & Management & Configuration & Management \\
\hline ర్థ & $\begin{array}{l}\text { Evaluation of project alterna- } \\
\text { tives } \\
\text { Comparison and optimization } \\
\text { of design alternatives } \\
\text { Components / equipment } \\
\text { procurement and construction } \\
\text { alternatives evaluation } \\
\text { spare parts requirements esti- } \\
\text { mation. [4], [13], [2], [17] }\end{array}$ & $\begin{array}{l}\text { - Communicating value to - } \\
\text { the customer and selling } \\
\text { support } \\
\text { - Propose to the clients } \\
\text { specific design solutions } \\
\text { - Pricing } \\
\text { - Contracting maintenance } \\
\text { services provision } \\
\text { [4], [13], [17], [19] }\end{array}$ & $\begin{array}{l}\text { - Evaluation of design } \\
\text { alternatives offered by a } \\
\text { provider } \\
{[6]}\end{array}$ & $\begin{array}{l}\text { - Suppliers and tenders } \\
\text { evaluation \& selection } \\
\text { - Maintenance service } \\
\text { contract evaluation } \\
\text { - Investment, budget } \\
\text { planning, cost control } \\
\text { [13], [5],[17], [22] }\end{array}$ \\
\hline${ }^{0}$ & $\begin{array}{l}\text { Proposal of re-configuration } \\
\text { solutions }\end{array}$ & $\begin{array}{l}\text { - Maintenance service } \\
\text { provision offering } \\
\text { - Spare parts provision } \\
\text { offering }\end{array}$ & $\begin{array}{l}\text { - Reconfiguration decisions - } \\
\text { - WIP sizing } \\
\text { [21] }\end{array}$ & $\begin{array}{l}\text { - Maintenance scheduling } \\
\text { and management } \\
\text { - Repair level analysis } \\
\text { - Asset utilization and } \\
\text { production strategies } \\
\text { [3],[14],[13] }\end{array}$ \\
\hline $\begin{array}{l}\overrightarrow{1} \\
\text { 어 }\end{array}$ & $\begin{array}{l}\text { Proposal of reconfiguration for } \\
\text { EoL optimization }\end{array}$ & $\begin{array}{l}\text { - Evaluation and proposal - } \\
\text { of rehabilitation strategies }\end{array}$ & $\begin{array}{l}\text { - Reuse strategies for } \\
\text { components / machines }\end{array}$ & $\begin{array}{l}\text { - Evaluation of rehabilita- } \\
\text { tion strategies } \\
{[2],[18],[22]}\end{array}$ \\
\hline
\end{tabular}


What emerged is that TCO is useful in asset provider - asset user communication, and helps in trade-off analyses of system concepts (Heilala et al., 2006). The core aim of a TCO evaluation is to avoid problem shifting decisions by keeping an integrating perspective.

\subsection{The industry-influence}

An additional aspect that emerged from the literature analysis is about the influence of the type of industry a company belongs to, on the value given to TCO analysis. The TCO concept was firstly introduced for procurement purposes by the US Department of Defense in 1960 and its importance in defense was stimulated by findings that operation and support costs for typical weapon systems accounted for as much as $75 \%$ of the total cost (Asiedu and $\mathrm{Gu}, 1998$ ). Since then the need for more extensive application of engineering economy methodologies in the planning and control of production systems has been more and more recognized. The applications of LCC analysis have then spread to other industries such as oil and chemical industries (Kawauchi and Rausand, 1999). Not surprisingly, the concept originally spread among the process industry and more in general in capital-intensive industries where physical asset management represents a strategic resource given the high vulnerability to disturbances and the need for production / operation regularity that characterize them. Currently, the interest for TCO is rising in the discrete manufacturing industry too. In fact, the emergent global competition is forcing companies to estimate and optimize the overall system life cycle cost with reference to performance, safety, reliability and maintainability (Waghmode and Sahasrabudhe, 2012) to be able to compete not only on price, but also on cost effectiveness and technological leadership (Lad and Kulkarni, 2008). More and more contracts are based on TCO evaluation in several sectors such as the automotive, the packaging and the food sectors. Table 2 presents the concept emerged highlighting the critical factors connected to the TCO relevance for capital-intensive and discrete manufacturing industries.

Table 2. Relevance and critical factors of TCO in process and manufacturing industries

\begin{tabular}{c|cc}
\hline Type of industry & \multicolumn{1}{c}{ Critical factors } & \multicolumn{1}{c}{ TCO relevance } \\
\hline $\begin{array}{c}\text { Process industry } \\
\text { (power, mining and oil, } \\
\text { chemical sectors...) }\end{array}$ & $\begin{array}{l}\text { - capital-intensive assets } \\
\text { high vulnerability to disturbances need } \\
\text { for production regularity }\end{array}$ & $\begin{array}{l}\text { - High strategic relevance of TCO for } \\
\text { supporting decision making in physi- } \\
\text { cal asset management }\end{array}$ \\
\hline $\begin{array}{c}\text { Discrete } \\
\text { manufacturing }\end{array}$ & $\begin{array}{l}\text { high competition and need to compete } \\
\text { on cost effectiveness and technological } \\
\text { leadership than just on price }\end{array}$ & $\begin{array}{l}\text { TCO is getting more and more rele- } \\
\text { vance to demonstrate value for money } \\
\text { of investments. }\end{array}$ \\
\hline
\end{tabular}

\section{Practical implications: empirical evidences}

In order to corroborate the developed framework from an empirical point of view a case study was developed. The aim is to understand if the benefits that have been identified in literature are recognized in practice and which are the limitations for the adoption of TCO. Two companies belonging to different industries were selected. Company $\mathrm{A}$ is a small medium company in the discrete manufacturing industry while 
company $\mathrm{B}$ is a big company belonging to the process industry. They have different perspectives on asset management since company A is asset provider while company $\mathrm{B}$ is asset user. These differences have been selected referring to the different dimensions of the framework, and to the industry dependency highlighted in section 3 . The case has been based on semi-structured interviews and on a defined questionnaire.

A first aspect that emerged from the case study is the different involvement and interest in using the TCO in different life cycle phases depending on the kind of stakeholder the two companies represent. Indeed, Company A (provider) declared to be directly involved and being able to take decisions mostly in the BoL phase. In fact, the company is responsible of the design and installation of the asset it produces and its role in the MoL phase is limited to providing the clients with manuals and guidelines for the maintenance activities. No service is provided in this case by A to its clients. On the other side, Company B is an asset user and it is directly interested in the management of its assets in the MoL phase and in the evaluation of investments for new installations. It has to be specified that Company A recently started to look at $\mathrm{TCO}$ as a potential tool and is now pushing its importance at strategic level; instead for Company B the TCO concept is consolidated even if it is still looking for a tool able to integrate technical evaluation into cost estimations. The following table refers to the proposed framework and shows which are the decisions that TCO evaluation can support according to the judgments of the two companies; based on the relevance for the business.

Table 3. The TCO benefits: results from the case study

\begin{tabular}{|c|c|c|c|c|}
\hline & \multicolumn{2}{|c|}{ COMPANY A (ASSET PROVIDER) } & \multicolumn{2}{|c|}{ COMPANY B (ASSET USER) } \\
\hline & Configuration & Management & Configuration & Management \\
\hline - & $\begin{array}{l}\text { Comparison and optimiza- } \\
\text { tion of design alternatives }\end{array}$ & $\begin{array}{l}\text { - Communicating value to } \\
\text { the customer and selling } \\
\text { support } \\
\text { - Propose the clients specific } \\
\text { design solutions }\end{array}$ & $\begin{array}{l}\text { - Evaluation of design } \\
\text { alternatives }\end{array}$ & $\begin{array}{l}\text { - Suppliers and tenders evalua- } \\
\text { tion \& selection } \\
\text { - Maintenance service contract } \\
\text { evaluation } \\
\text { - Investment, budget planning, } \\
\text { cost control }\end{array}$ \\
\hline$\sum^{-1}$ & $\begin{array}{l}\text { - System reconfiguration } \\
\text { proposals }\end{array}$ & $\begin{array}{l}\text { - Possibility to develop } \\
\text { service offering }\end{array}$ & $\begin{array}{l}\text { - Reconfiguration deci- } \\
\text { sions }\end{array}$ & $\begin{array}{l}\text { - Maintenance scheduling and } \\
\text { management } \\
\text { - Repair level analysis }\end{array}$ \\
\hline
\end{tabular}

The results from the two cases endorse what was expected by the literature and confirm the benefits defined in the framework. The case study was also useful to identify the main limitations in the adoption of TCO in practice. In particular, the main findings that emerged are the following:

- both companies assessed the need for a TCO tool able not only to consider all the relevant cost items along the asset lifecycle, but also the technical aspects that have influence on it (the authors developed a literature review about this issue in (Roda and Garetti, 2014));

- there is the need for a reliable database with both economic and technical parameters to be used for the TCO evaluation; in particular, the main problem for Company $\mathrm{A}$ is the necessity for a strict collaboration with its customers in order to get da- 
ta for the evaluation of the OPEX of the asset under analysis; while Company B needs to focus on a system able to record relevant data regarding the behavior of its asset (failures events, set-up times etc.);

- the use of the TCO at the disposal phase is not considered as a relevant issue for both companies at the moment;

- general desires to minimize the initial expenditures in order to increase return on investment, and general lack inside the organizations of the adequate consideration of the asset life cycle that requires inter-functional cooperation and alignment;

- in general, TCO is seen as a powerful communication tool by both kind of stakeholders, being able to inform different kind of actors, the customers but also the top management by supplying the value of the asset through the language of money, eventually incorporating technical considerations.

\section{Conclusions and future research}

The paper presents a framework that describes the main applications and benefits that the evaluation of the TCO of industrial asset has got both for asset users and asset providers along the asset life cycle. Moreover, a case study analysis was implemented for an empirical assessment. The investigation confirmed that TCO represents a useful indication for guiding asset managers in the decision making process for harmonizing the never ending conflicts by focusing on facts, money, and time (Barringer, 2003) and, if properly estimated it does represent a competitive advantage for companies. It was possible to identify benefits of TCO for decision-making support at each life cycle phase of an asset and it emerged that its application can have positive effect on cost control, management of the asset, investments evaluation, sales and marketing strategy support, etc. Nevertheless, up to day, there are still a number of difficulties that limit a TCO model widespread adoption by industry. This problem emerged from the case study and it is a fact that there is no single calculation model that has been accepted in practice as a standard so far. The research plan of the authors of this paper is to develop a generalizable TCO evaluation methodology based on a critical analysis of some of the existing proposed solutions that go in this direction too. Future research should try to overcome the adoption limitations by identifying which are the existing barriers and defining a methodology for evaluating TCO that can be used as a real support in decision making. A step of the research may include widening to other companies the industrial assessment through the case study development to better identify the practical adoption's criticalities.

\section{References}

1. Amadi-Echendu, J., 2004. Managing physical assets is a paradigm shift from maintenance. In: Engineering Management Conference, Proceedings. IEEE International. pp. 1156-1160.

2. Asiedu, Y., Gu, P., 1998. Product life cycle cost analysis: State of the art review. International Journal of Production Research 36, 883-908. 
3. Barringer, H., 2003. A life cycle cost summary. In: Conference of Maintenance Societies (ICOMS $\left.{ }^{\circledR}-2003\right)$. pp. 1-10.

4. Carpentieri, M., Papariello, M., 2006. A life cycle cost framework for automotive production lines. In: 3th CIRP International Conference on LCE. pp. 711-716.

5. Ellram, L., Siferd, S., 1998. Total cost of ownership: a key concept in strategic cost management decisions. Journal of Business Logistics 19, 55-84.

6. Fabrycky, W.J., Blanchard., B.S., 1991. Life-cycle cost and economic analysis.

7. Heilala, J., Helin, K., Montonen, J., 2006. Total cost of ownership analysis for modular final assembly systems. International Journal of Production Research 44, 3967-3988.

8. IAM, 2012. Asset Management - an anatomy.

9. ISO 55000:2014(E), 2014. Asset management - Overview, principles and terminology.

10. Jönsson, M., Andersson, C., Ståhl, J.-E., 2013. Conditions for and development of an information technology-support tool for manufacturing cost calculations and analyses. International Journal of Computer Integrated Manufacturing 26, 303-315.

11. Kawauchi, Y., Rausand, M., 1999. Life Cycle Cost (LCC) analysis in oil and chemical process industries. Toyo Engineering Corp, Chiba.

12. Komonen, K., Kortelainen, H., Räikkonen, M., 2006. An asset management framework to improve longer term returns on investments in the capital intensive industries. In: London, S. (Ed.), Engineering Asset Management. pp. 418-432.

13. Korpi, E., Ala-Risku, T., 2008. Life cycle costing: a review of published case studies. Managerial Auditing Journal 23, 240-261.

14. Lad, B.K., Kulkarni, M.S., 2008. Integrated reliability and optimal maintenance schedule design: a Life Cycle Cost based approach. Int. Journal of Product Lifecycle Mngmt 3, 78.

15. Parra, C., Crespo, A., Moreu, P., 2009. Non-homogeneous Poisson Process (NHPP), stochastic model applied to evaluate the economic impact of the failure in the Life Cycle Cost Analysis (LCCA). Safety, Reliability and Risk Analysis: Theory, Methods and Applications 929939.

16. Roda, I., Garetti, M., 2014. The link between costs and performances for Total cost of Ownership evaluation of physical asset State of the art review. ICE 2014 Proceeding, to Be Published.

17. Schuman, C. a., Brent, A.C., 2005. Asset life cycle management: towards improving physical asset performance in the process industry. International Journal of Operations \& Production Management 25, 566-579.

18. Shahata, K., Zayed, T., 2008. Simulation as a tool for life cycle cost analysis. In: Proceedings of the 40th Conference on Winter Simulation. pp. 2497-2503.

19. Snelgrove, T., 2012. Value pricing when you understand your customers: Total cost of ownership-Past, present and future. Journal of Revenue \& Pricing Management 11, 76-80.

20. Tam, A.S.B., Price, J.W.H., 2008. A generic asset management framework for optimizing maintenance investment decision. Production Planning \& Control 19, 287-300.

21. Tomasella, M., Parlikad, A.K., 2012. Through-life management of engineering assets. In: Engineering Asset Management and Infrastructure Sustainability. Springer London, pp. 931944.

22. Waghmode, L.Y., Sahasrabudhe, A.D., 2012. Modelling maintenance and repair costs using stochastic point processes for life cycle costing of repairable systems. International Journal of Computer Integrated Manufacturing 25, 353-367.

23. Woodward, D., 1997. Life cycle costing - theory, information acquisition and application. International Journal of Project Management 15, 335-344. 